\title{
CAMP? CAUBY! entre o conceito e o encanto
}

\author{
Cláudia Neiva de Matos \\ (UFF/CNPq) \\ https://orcid.org/0000-0001-5939-986X
}

\section{RESUMO}

No ensaio "Notes on camp", de 1964, Susan Sontag trouxe para os debates acadêmicos a noção e o termo "camp", designando um conjunto de práticas e valores da estética visual e performática então em voga no universo gay de Nova York. A cultura camp desenvolveu-se nas décadas seguintes e parece ter ganho novo vigor nos últimos anos, como mostrou o Met Gala de 2019, ao eleger o tema "Camp in Fashion". É difícil definir precisamente essa noção, atravessada por fatores subjetivos, como o gosto, e por questões ligadas à inserção sociocultural de objetos e observadores. O presente ensaio baseia-se principalmente no texto de Sontag e no "Terceiro manifesto camp" (2002), de Denilson Lopes, para elaborar aproximações ao conceito de camp. Por outro lado, a fim de perceber o modo como o estilo considerado camp é capaz de seduzir seus receptores, analisa o caso do cantor Cauby Peixoto, com seu amaneiramento, seus excessos e ambiguidades, sua voz privilegiada e suas fãs enlouquecidas. Com base em dados teóricos e históricos, mas também na experiência pessoal de assistir ao intérprete em cena, tento analisar a arte de Cauby e discutir se a noção de camp é adequada para caracterizá-la. Os impasses e aporias dessa discussão podem levar-nos a repensar certas posturas e funções da crítica diante dos objetos que pesquisa: como lidar com os encantos que problematizam e desafiam conceitos estéticos academicamente consagrados, sem rejeitar o encantamento nem renunciar à conceituação?

PALAVRAS-CHAVE: Camp; Cauby Peixoto; crítica literária; canção; performance 


\section{CAMP? CAUBY! between the concept and the enchantment}

\section{ABSTRACT}

In "Notes on camp" (1964), Susan Sontag brought to the academic debate the notion and the term "camp", meaning a set of practices and values of the visual and performatic aesthetics then in vogue in New York's gay scene. Camp culture developed in the following decades and seems to have gained new momentum in recent years, as can be seen in Met Gala 2019's choice of "Camp in Fashion" as its theme. Camp is a hard notion to define; it is pervaded with subjective elements such as taste and with issues relating to the sociocultural roles of objects and observers. This paper draws mainly on Sontag's essay and on Denilson Lopes' "Third Camp Manifesto" (2002) to weave a discussion of the concept of "camp". On the other hand, in order to explore the way camp is able to seduce its viewers, this paper examines Brazilian singer Cauby Peixoto and his performatic mannerisms, excesses and ambiguities, his privileged voice and frantic fans. Using theoretical and historical data as well as my personal experience of watching him on stage, I try to analyse Peixoto's art and discuss whether the notion of camp is adequate to characterize it. The dilemmas and conundrums of such discussion may lead us to think over certain attitudes and functions of criticism towards its research objects: how does one deal with the wonder that problematizes and challenges academically valued aesthetic concepts without rejecting either the enchantment or the act of conceptualizing?

KEYWORDS: Camp; Cauby Peixoto; literary criticism; song; performance 


\section{A festa no Museu e o Seminário na UERJ ${ }^{1}$}

Já faz tempo que universidades, museus e outras instituições dedicadas ao conhecimento científico e à chamada alta cultura concedem espaço e interesse a fenômenos supostamente frívolos e efêmeros. A moda, por exemplo, é objeto relevante de estudo e documentação, configurando um campo cheio de significados estéticos, históricos e sociais. O Metropolitan Museum of Art de Nova York abriga, desde 1959, um Costume Institute que, a cada ano, promove um baile de gala destinado, entre outras coisas, a angariar fundos para o sustento da instituição. Em maio deste ano de 2019, o Met Gala elegeu o tema "Camp in Fashion". Lady Gaga, uma das co-anfitriãs do evento, fez uma entrada triunfal a bordo de um imenso vestido pink-shock que se metamorfoseou e reduziu até a versão final de lingerie preta. Foi considerado o mais sensacional look da noite ${ }^{2}$.

Na mesma ocasião, abriu-se no Met uma exposição que, valendo-se do rico acervo do Costume Institute, mostrava o camp em perspectiva histórica e estética. Max Hollein, diretor do Museu, declarou:

Camp's disruptive nature and subversion of modern aesthetic values has often been trivialized, but this exhibition will reveal its profound influence on both high art and popular culture. By tracing its evolution and highlighting its defining elements, the show will embody the ironic sensibilities of this audacious style, challenge conventional understandings of beauty and taste, and establish the critical role this important genre has played in the history of art and fashion." (Camp: Notes on Fashion, 2019)3.

1 Agradeço ao CNPq pela bolsa de pesquisa que contribuiu para a realização deste trabalho.

2 Os looks de Lady Gaga no Met Gala 2019 podem ser vistos em:

https://s3.reutersmedia.net/resources/r/?m=02\&d=20190507\&t=2\&i=138439871 5\&r=LYNXNPEF4606P

3 "A natureza disruptiva do Camp e sua subversão dos valores estéticos modernos têm sido frequentemente trivializadas, mas esta exposição revelará sua profunda influência tanto na arte erudita quanto na cultura popular. Traçando sua evolução e destacando seus elementos definidores, a mostra vai incorporar as sensibilidades irônicas desse estilo audacioso, desafiar noções convencionais de beleza e gosto e estabelecer a função crítica que esse importante gênero desempenhou na história da arte e da moda." Esta e as demais traduções são de minha responsabilidade. 
"Art and fashion", arte e moda, são certamente terrenos propícios à expressão camp, largamente construída de visualidade e performance. $\mathrm{E}$ um dos objetivos da exposição, segundo Hollein, era justamente revelar a importância do camp na configuração dos valores estéticos contemporâneos, articulando arte "elevada" e cultura popular, celebrando a conciliação contemporânea dessas duas esferas, a parceria entre o museu e a moda.

Talvez alguns leitores se estejam perguntando o que exatamente significa "camp". Ao contrário do que ocorreu nos Estados Unidos, esse termo nunca logrou grande circulação em linguagem corrente ou acadêmica no Brasil. Apesar disso, muitas feições do que ele significa foram frequentes na arte e na sociedade brasileiras, com suas faces carnavalescas e carnavalizadas, seus trejeitos de país tropical, suas práticas de travestimento, vinculadas ou não ao universo LGBT.

A etimologia da palavra é obscura, mas supõe-se que está ligada ao inglês to camp, acampar. Embora manifestações do seu sentido estético e social tenham existido desde sempre, foi provavelmente no início do século passado que o termo assumiu o significado que ainda hoje carrega, em linhas gerais. O Oxford English Dictionary registrou-o, em 1909, com o sentido de "ostensivo, exagerado, afetado, teatral; efeminado ou homossexual; pertencente a, característica de, homossexuais." (Estilo Camp, 2019).

Nos anos 1950-60, o camp vigorava num âmbito restrito e marginalizado, cujo núcleo seria a cena underground, gay e performática de Nova York. O imaginário e as figurações por ele inspirados se multiplicaram nas décadas seguintes. Sua mistura de exagero, ousadia e humor se manifestou, por exemplo, no cinema de John Waters (Pink Flamingos, 1972; Hairspray,1988) e Pedro Almodóvar (Mulheres à beira de um ataque de nervos, 1988; De salto alto, 1991), bem como nas drag queens e nas cantoras Cher e Madonna. 


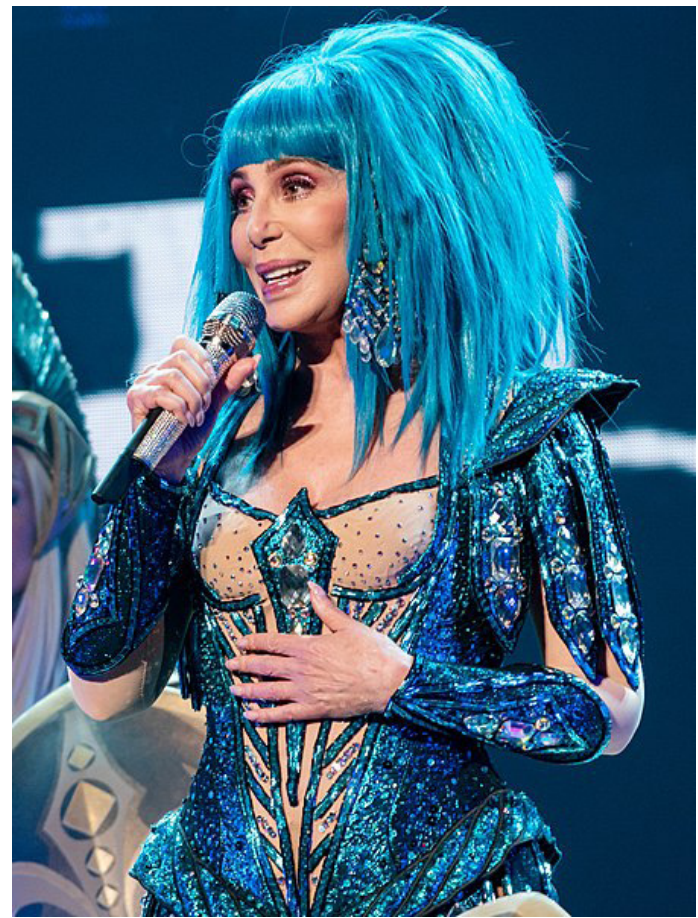

Fig.1: Cher, 2019.

Autor:Raph_PH

https://commons.wikimedia.org/wiki/File:CherO2201019-6_(48933060976)_cropped.jpg

Sem restringir-se ao universo gay, os modos camp de ser e aparecer também marcaram presença em outros grupos socioculturais, com diferentes formatos e nuances. Mas o estilo permaneceu vinculado sobretudo às propostas e demandas estéticas e políticas do movimento LGBT, como dispositivo poderoso de construção e afirmação identitárias. Nas últimas décadas, a expansão dos movimentos do orgulho gay e a relevância crescente das questões de gênero, motivando o ativismo social e as pesquisas acadêmicas, deram ao camp uma atualidade e consistência que talvez fossem difíceis de prever naqueles anos 60 , quando pela primeira vez ele foi tomado a sério pelos intelectuais.

Foi a partir do célebre ensaio de Susan Sontag "Notes on 'Camp"” (1964) que a crítica cultural começou a prestar atenção ao camp, conferindo-lhe visibilidade e reconhecimento letrado. A proposta camp foi adotada 
pelos intelectuais como parte da defesa antiacadêmica da cultura popular e mediática. Sua popularidade entre os scholars aumentou nos anos 1980, com a difusão de pontos de vista pós-modernos na arte e na cultura. Mas seu prestígio oscilou no correr do tempo, ameaçado por acusações de esvaziamento político e banalização comercial.

Rejeição e simpatia alternam-se e misturam-se nas avaliações que dele se fazem. O baile e a exposição de 2019 no Metropolitan Museum de Nova York são ocorrências recentes de um movimento de revalorização que já se desenrola há vários anos, tanto na cultura do espetáculo quanto no mundo acadêmico. Por outro lado, a intimidade do camp com o pop mais ligeiro, seus traços em comum com o kitsch e o trash, bem como sua forte vinculação à cultura gay, contribuem para gerar e manter a seu respeito nocionamentos preconceituosos e redutores. A edição brasileira da Wikipedia dedica-lhe não mais que um par de parágrafos, definindo o termo, de saída, como "uma gíria para comportamento, atitude ou interpretação exagerada, artificial ou teatral; ou ainda um adjetivo que significa algo de mau gosto, muito artificial, exagerado, 'cafona' ou 'brega'." ("Camp", 2019)

A conduta estética e moral do camp, que lhe assegura espaço na mídia e no mundo digital, também suscita antipatias, mais ou menos dissimuladas, por parte de certos segmentos da imprensa. Os argumentos são às vezes de caráter político, invocando a hegemonia do mercado na sociedade do espetáculo para minimizar sua legitimidade cultural. Mas nota-se também certo apego renitente ao "bom gosto" das elites educadas nos discursos que desprezam ou ridicularizam a estética camp. Em 2012, Arthur Dapiève apontava Lady Gaga como "a representante mais notória" da versão contemporânea do camp, quando este

[...] parece ter deixado de ser um nicho de mercado para se tornar o próprio mercado. [...] Numa era em que as pessoas fazem qualquer coisa para aparecer, só triunfam de verdade aquelas que se jogam sem pudor em um estilo que tem até nome-cabeça e voltou à moda: o camp.

E disparava: "No Brasil, o camp pode ainda ser percebido como o primo rico do brega." (DAPIÈVE, 2012)

A propósito do Met Gala de 2019, o jornalista Pedro Diniz escreveu que o camp contemporâneo, surgido no contexto da luta por direitos civis nos Estados Unidos, nas últimas décadas do século XX, "passeou" pelos movimentos de "ebulição social" que se seguiram, mas perdeu o vigor político original: 
[...] na conjuntura geopolítica nervosa de hoje, [o camp] volta a pairar sua teatralidade na cultura pop. Mas há um ingrediente novo, tão dourado quanto o look usado pelo ator Billy Porter [no baile do Met]: a forma como o mercado lucra com o modismo. (DINIZ, 2019)

Talvez o camp tenha mesmo perdido algo do potencial contestatário e questionador dos anos 1960, quando se associou a uma verdadeira revolução na história da diversidade dos gêneros, participando da contracultura e da fermentação social que resultou nos motins de Stone Wall no final da década e no ativismo gay dos anos 1970. Mas, antes e depois daqueles tempos, e ainda hoje, o fato é que figuras e obras claramente campy permanecem capazes de seduzir, intrigar e... incomodar. A potência do camp resiste, porque não está somente na sua aptidão para encarnar a rebeldia ou meramente fazer "moda". Artificialidade e excesso, sempre invocados para vesti-lo e travesti-lo, são elementos cruciais de seus ícones, mas não dão conta de seus modos complexos de ser e aparecer.

Até hoje difícil de circunscrever como conceito estético ou antropológico, causador de estranheza e às vezes desconforto para o receptor culto e crítico, o camp continua resistindo às apreciações e definições estanques. "To talk about Camp is [...] to betray it", escreveu Susan Sontag (2013:1). Qualquer descrição breve que dele se faça será parcial ou injusta - e isso sinaliza sua amplitude e complexidade. Parece fácil usá-lo como adjetivo para muitas coisas e imagens do mundo passado e contemporâneo, porém difícil compreender sua substância, seu ser substantivo. Afinal, o camp sempre foi, de certa forma, deliberadamente "superficial"; e sempre carregou muitas camadas de sentido sob a superfície, tornando difícil aprisionar seu estranho encanto num conceito pensável.

Em 2013, realizou-se na UERJ o Seminário "Camp! Afetos e Poses", articulado com uma exposição e mostra de filmes intitulada "CAMP! Arte e Diferença”. A iniciativa, original e oportuna, deveu-se principalmente a Denilson Lopes, organizador do evento e um dos poucos scholars brasileiros dedicados ao tema, sobre o qual publicou diversos textos. Falarei adiante sobre seu "Terceiro Manifesto Camp", que oferece uma excelente e segura introdução ao tema, com apoio em extensa bibliografia.

Convidada a participar do seminário na UERJ, inicialmente hesitei um pouco sobre o caminho que tomaria para abordar o assunto, que não me era então, na verdade, muito familiar. Por sorte, antes mesmo que eu

4 "Falar sobre o Camp é [...] traí-lo." 
começasse a caçar bibliografia para refletir sobre o conceito, seu conteúdo ou alcance, irrompeu na minha memória visual e auditiva a lembrança de algo que eu tinha certeza de poder identificar como camp. Lembrei-me do cantor brasileiro Cauby Peixoto. ${ }^{5}$

Eu conhecia Cauby desde a infância, inicialmente por escutá-lo cantar no rádio; mais tarde, por alguns discos e shows. Já havia publicado uma análise de "Bastidores", canção de Chico Buarque que ele gravara em 1980. Mas nunca me passara pela cabeça estudar Cauby... Era um artista da canção brasileira que há muito despertava minha atenção e simpatia, mas para o qual parecia difícil encontrar um lugar no meu quadro de pesquisas - bem como, aliás, no quadro de pesquisas em geral das áreas acadêmicas que tratam da canção. Acho que, naquela época, ninguém ainda tinha falado de Cauby no âmbito universitário. Talvez porque ele fora e era, justamente, um artista demasiado... camp.

O presente texto, tratando de camp e de Cauby, inclui quase tudo que escrevi para o Seminário (e não chegou a ser publicado), combinado a uma parte (um pouco mais acadêmica) recentemente elaborada. Se resolvo agora retomar e estender o trabalho de seis anos atrás, é porque (além naturalmente de esperar que ele possa contribuir de algum modo para os estudos da canção popular e das linguagens estéticas de massa) penso que Cauby merece ser lembrado, reconhecido e louvado. E também porque quando, já professora universitária de Literatura, descobri que gostava de Cauby, isso me trouxe uma sensação curiosa, um impulso de perguntar: "por quê?" O que me seduzira e continuava a seduzir naquela figura estranha? Ao levantar agora tais questões, trato de juntar camp e Cauby na mesma reflexão, o que é também uma boa oportunidade de enfrentar as dificuldades que há em conciliar conceitos e encantos.

\section{Notas sobre o camp... e sobre a canção popular}

A exposição do MET chamou-se "Camp: Notes on Fashion", evocando o título de um famoso e já antigo ensaio crítico, no qual se baseou a organização do evento. Tratava-se de "Notes on 'Camp", que Susan Sontag lançou em $1964^{6}$, indagando-se pioneiramente sobre o termo e seu sentido.

5 Ainda vivo na época, Cauby Peixoto (1931-2016) morreria pouco depois, aos 85 anos.

6 Esta é a data da primeira publicação do ensaio, na Partisan Review. Dois anos depois, ele apareceu integrando o livro de Sontag Against Interpretation. 
Ainda hoje todas as reflexões a esse respeito não deixam de referir-se àquele ensaio fundamental.

Já nas primeiríssimas linhas, a autora explicita o ineditismo de seu tema; e dá a pista, não apenas do próprio objeto de que vai tratar, mas das dificuldades que pode haver em abordá-lo.

Many things in the world have not been named; and many things, even if they have been named, have never been described. One of these is the sensibility - unmistakably modern, a variant of sophistication but hardly identical with it - that goes by the cult name of "Camp." A sensibility (as distinct from an idea) is one of the hardest things to talk about; but there are special reasons why Camp, in particular, has never been discussed." (SONTAG, 2013, p. 1) ${ }^{7}$

Trata-se pois de uma sensibilidade que anima as criações da cena camp; mas também da sensibilidade dos receptores ao que o camp lhes oferece. A própria autora mostra-se sensível ao camp, à sua inegável modernidade e peculiar sofisticação. Porém não possui sobre ele nenhuma ideia assentada. É um "cult name" que circula informalmente dentro de um âmbito limitado e ainda não frequenta debates intelectuais. Sem recorrer a muita base bibliográfica e a nenhuma crítica (pois nunca até então se escrevera sobre o camp), Sontag vai dar existência teórica ao termo, ampliando-lhe o sentido e trazendo-o para o debate acadêmico. Mas o que a move é menos uma demanda intelectual "neutra" do que um conflito que o próprio camp suscita dentro dela. $\mathrm{O}$ desafio de circunscrever conceitualmente seu objeto parece-lhe fadado ao insucesso, a ser uma espécie de "traição". Mas é também uma oportunidade de levantar e elaborar questões profundamente pessoais, de natureza ética e estética:

If the betrayal can be defended, it will be for the edification it provides, or the dignity of the conflict it resolves. For myself, I plead the goal of selfedification, and the goad of a sharp conflict in my own sensibility. I am strongly drawn to Camp, and almost as strongly offended by it. That is why I want to talk about it, and why I can. (SONTAG, 2013, p. 1) ${ }^{8}$

7 "Muitas coisas no mundo não foram nomeadas; e muitas coisas, mesmo tendo sido nomeadas, nunca foram descritas. Uma delas é a sensibilidade - inequivocamente moderna, uma variante da sofisticação mas dificilmente idêntica a ela - que atende pelo nome cult de "Camp." Uma sensibilidade (distinta de uma ideia) é uma das coisas sobre as quais é mais difícil falar; mas há razões especiais pelas quais o Camp, em particular, nunca foi discutido."

8 "Se a traição puder ser defendida, há de ser pela edificação que proporciona, ou 
Como expressão e motor de sensibilidade, o camp coloca necessariamente, para o receptor, a questão do gosto. Bom gosto? Mau gosto? A dicotomia poderia tornar-se irrelevante diante da potência afirmativa da imagem camp, sustentada pela adesão de uma comunidade ampla. Mas às vezes o receptor "qualificado" não consegue livrar-se dela - e isso pode ser uma das razões de seu desconforto. Para enfrentar a questão, Sontag procura situá-la social e historicamente, vendo o gosto camp como "part of the history of snob taste", patrocinada por um tipo particular de elite:

an improvised self-elected class, mainly homosexuals, who constitute themselves as aristocrats of taste. [...] homosexuals, by and large, constitute the vanguard - and the most articulate audience - of Camp. (SONTAG, 2013, p. 9-10) ${ }^{9}$

Desde os anos 60 até o presente, a trajetória do camp confirmou sua ligação indescartável, embora não exclusiva, com a cultura LGBT. No ensaio de Sontag, entretanto, o fator gay ocupa bem poucos parágrafos. Sua precedência e importância, embora reconhecidas, são confinadas a uma circunstância histórica quase acidental:

Nevertheless, even though homosexuals have been its vanguard, Camp taste is much more than homosexual taste. [...] Yet one feels that if homosexuals hadn't more or less invented Camp, someone else would. (SONTAG, 2013, p. 10) $)^{10}$

A autora provavelmente revisou, mais tarde, sua abordagem. Naquele primeiro momento, seria difícil prever a expansão e o incremento de visibilidade que a comunidade e a cultura gay lograriam nas décadas seguintes, bem como a extensão e relevância que essa cultura, notadamente em seus aspectos visuais e performáticos, ganharia em escala mun-

pela dignidade do conflito que resolve. Da minha parte, apoio a meta da autoedificação, e o estímulo de um conflito agudo na minha própria sensibilidade. Sou fortemente atraída pelo Camp, e quase tão fortemente ofendida por ele. É por isso que eu quero e posso falar sobre ele."

9 "uma classe autoeleita improvisada, principalmente homossexuais, que se constituem como aristocratas do gosto. [...] Os homossexuais, em geral, constituem a vanguarda - e a audiência mais articulada - do Camp."

10 "No entanto, embora os homossexuais tenham sido a sua vanguarda, o gosto Camp é muito mais do que um gosto homossexual. [...] a gente sente que, se os homossexuais não tivessem mais ou menos inventado o Camp, alguém mais teria feito isso." 
dial. Seria igualmente difícil imaginar a força que a linguagem camp teria - entre outras - na configuração e afirmação dessa cultura, participando de suas lutas políticas e sociais.

Sontag foi, às vezes, criticada por não haver focado o sentido político do camp. Mas, se forçosamente lhe faltava uma perspectiva temporal capaz de instruir sua visão histórica, por outro lado, suas intuições e percepções estéticas a esse respeito revelaram-se muito consistentes, a tal ponto que seu texto é referência obrigatória até hoje para quem quer que se refira ao assunto. A autora abraçou a noção de maneira muito rica e multifacetada, de um modo talvez ainda inigualado. E fez isso por meio de "notas": "Notas sobre o "Camp". Para falar do camp - e da sua relação com ele - escolheu um discurso fragmentado e algo dispersivo, porém dotado de cerrada coerência, que aos poucos se constrói no conjunto do texto.

Um dos fatores dessa construção é a abundância e variedade de exemplos mencionados por Sontag. Desde então, vários escritos sobre camp seguiram esse modelo: quando se fala sobre camp, uma das atitudes mais correntes é relacionar quem ou o que é ou não é camp. Ou seja, o conceito continua a ser delineado, em boa parte, pelo processo de atribuição do adjetivo. Há personagens, obras e objetos campy em diversas épocas e culturas. Elas se destacam, por exemplo, no período barroco e nos diferentes tipos de Maneirismo.

O camp pode manifestar-se em vários suportes e linguagens, mas sua feição mais evidente costuma ser associada a sensações e imagens visuais. Trata-se de uma sedução - nisso concordam a maioria dos que pensam o camp - fortemente estética. O camp provoca estesia: na verdade, antes mesmo de emocionar, parece capaz de oferecer ou despertar sensações fortes. Sua obsessão pelo estilo e pelo artifício privilegia a exterioridade, a qual, aparentemente, chega a constituir um valor em si, obliterando pelo menos à primeira vista - a demanda por "profundidade" semântica. Para Sontag, o camp pode brotar do contraste entre, por exemplo, uma forma rica e um conteúdo pobre. Por causa disso, a autora nota que é difícil associar camp com música de concerto: não possuindo "conteúdo" (sendo contentless), essa música não oferece a possibilidade do contraste.

Já no universo da canção popular, encontram-se com facilidade traços do estilo ou da cultura camp, e isso se torna possível e é motivado, principalmente, por três fatores:

a) a canção tem letra, e a letra propõe um conteúdo, um sentido referencial; 
b) a canção implica na presença ativa de uma voz; e o modo de cantar, a performance vocal, pode ser virtuosístico e exagerado, conforme convém ao camp.

c) ligado à voz, está um corpo, uma pessoa, o intérprete: a performance na arte da canção também é, muitas vezes, uma performance corporal, um espetáculo visual, ao vivo ou em mídia áudio-visual - o que oferece situação propícia ao gesto camp.

Temos assim, na linguagem da canção popular enquanto forma de expressão e produto do show business, um campo fértil para manifestações camp. Pelo seu componente espetacular e pela sua enorme capacidade de seduzir, fascinar e incitar à idolatria, o mundo da canção é bastante favorável à circulação e consumo de cultura camp, como apontava o título da mesa de que participei no Seminário da UERJ: "Canções e Divas".

De fato, tivemos várias divas camp na música popular brasileira. Carmen Miranda talvez seja a mais exemplar, principalmente por sua atuação no cinema americano, que fez dela um modelo de artifício, trejeitos, exagero e também, para seguir os critérios de Sontag, uma fonte de divertimento e humor.

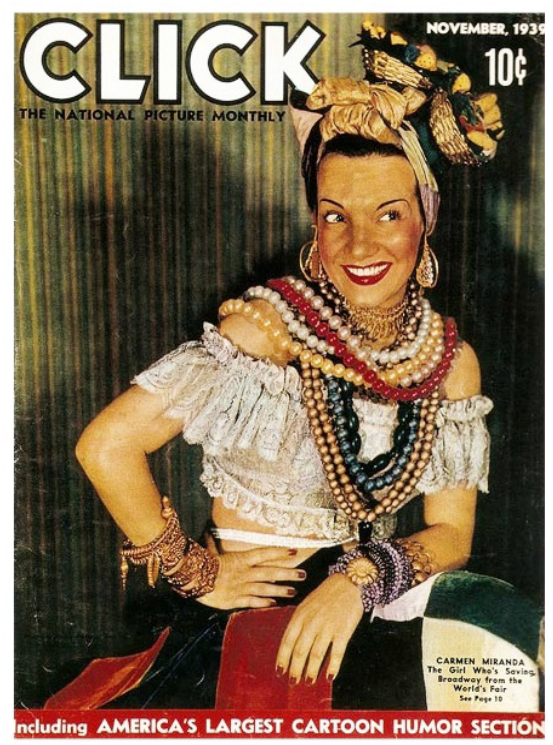

Fig. 2 : Carmen Miranda, 1939.

https://commons.wikimedia.org/wiki/File:Carmen_Miranda,_November_1939.jpgig. 
Mas há outras cantoras completamente diferentes que também podem ser consideradas camp. Por exemplo, Maria Bethânia, na qual o elemento camp é interiorizado, ligando-se à hipertrofia do sentimento dramático e desprezando o humor. Esse camp que não explora o humor e a brejeirice, mas sim o drama e o derramamento sentimental, também está patente no samba-canção abolerado dos anos 50, que consagra várias intérpretes femininas, como Angela Maria e Dalva de Oliveira. É a época da canção de fossa, que também ajuda a destacar compositoras, como Dolores Duran e Maysa.

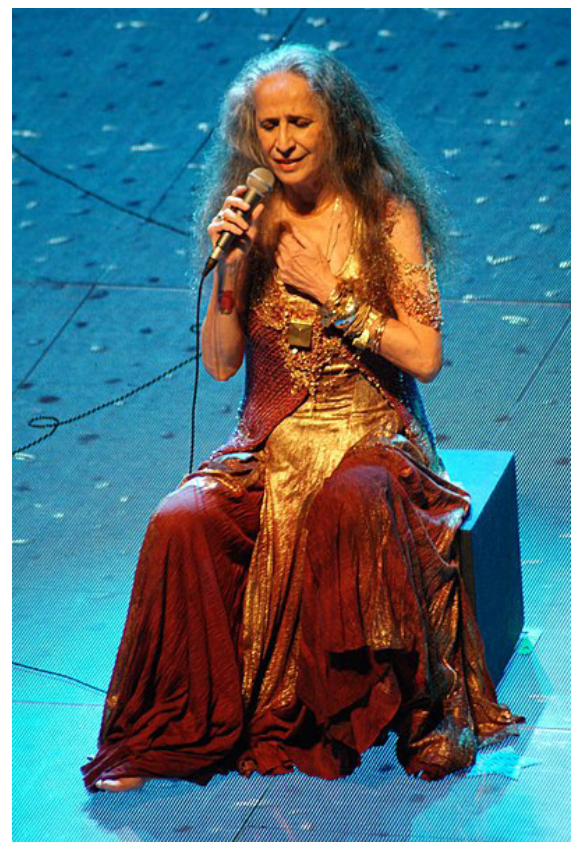

Fig. 3: Maria Bethânia, 2015.

Autor: Sebástian Freire

https://commons.wikimedia.org/wiki/File:Maria Beth\%C3\%A2nia no Vivo_Rio Turn\%C3\%AA_Abra\%C3\%A7ar_e agradecer_DSC00728_(20744971684).jpg

São as divas do gênero que domina o período imediatamente anterior à renovação da canção brasileira protagonizada por João Gilberto, Tom Jobim e Vinícius de Moraes. Segundo Rodrigo Faour, com as suas diversas inflexões, o samba-canção está diretamente ligado ao surgimento 
da bossa nova, a qual insurge-se contra ele ao mesmo tempo que com ele aprende. No transcorrer da década de 50, o samba-canção

se bifurca e toma duas vertentes: uma brega e uma chique. [§] Uma dessas vertentes bebia muito no sangue vermelho do bolero: o samba de fossa, que ao final da década de 1950 se transforma na música brega-romântica - caracterizada por um sentimentalismo exacerbado e letras recheadas de queixas de amor e culpas religiosas -, aparecendo ora como samba-canção ora como bolero, sendo difícil até diferenciar um do outro. A outra vertente, ao contrário, toma um rumo completamente diferente. Sofistica-se e vai gerar o samba romântico moderno, a bossa nova, que mais tarde se transformará mais ainda. (FAOUR, 2001, p. 49-50)

O autor chega a afirmar que, de certo modo, todo intérprete pré-anos 60 era obrigado a ser eclético. E tudo isso está na biografia que o próprio Faour escreveu sobre um cantor que, segundo ele, aderiu às duas vertentes, embora tenha ficado mais conhecido pela primeira: Cauby Peixoto.

\section{Um cantor: sua voz, seu empresário, seus fãs}

Eis que, entre as musas dos anos 50, destaca-se um ídolo masculino que parece ser um ótimo exemplo de camp na canção popular brasileira : Cauby Peixoto ${ }^{11}$. Podemos apontar a inflexão camp em vários aspectos de sua persona artística:

- a performance vocal, adornando sua bela e extensa voz de tenor com doses generosas de virtuosismo, exagero, amaneiramento, superinterpretação;

- a indumentária e o penteado afetados, extravagantes, que sofreram muitas críticas desde que começaram a ser adotados a partir dos anos 60 e foram desenvolvidos, sempre com mais exagero, até o final de sua carreira;

- a ambiguidade de sua orientação sexual, que sempre motivou muitas especulações, mas nunca chegou a ser valorizada ou explorada por Cauby em sua carreira artística;

- o repertório, variado, mas frequentemente compatível com o

11 Note-se que sua biografia, escrita por Rodrigo Faour com base em extensos depoimentos do próprio biografado e publicada em 2001 sob o título Bastidores: Cauby Peixoto: 50 anos da voz e do mito, é dedicada "a todos os cantores que, assim como Cauby, cultuam a voz e a interpretação. E em especial a cinco grandes divas da MPB de todos os tempos: Leny Eversong (in memoriam), Maysa (in memoriam), Lana Bittencourt, Angela Maria e Elza Soares.” (FAOUR, 2001, p. 5) 
estilo camp, inclusive no caso do samba-canção abolerado, gênero em que Cauby fez mais sucesso; isso sem deixar de retomar clássicos de muitos outros gêneros, sobretudo da canção americana, às vezes com traços jazzísticos;

- a presença do influxo norte-americano na construção de sua figura artística, referida em parte à imagem dos seus próprios ídolos (Nat King Cole, Frank Sinatra) e de outros ídolos da época, e alimentada pelas temporadas em que, sem grande êxito, tentou carreira nos Estados Unidos, sob os pseudônimos Roy Coby e Coby Dijon;

- a performance no palco, também influenciada pelo show business norte-americano;

- o comportamento das fãs, que nos tempos áureos do rádio expressavam sua adoração com gritos e gestos de desvario, num ritual de excessos que não deixava de ser estimulado pelo marketing do artista, operado com astúcia pelo empresário Di Veras ${ }^{12}$;

- o fato de sua figura artística e a popularidade alcançada terem sido em boa parte atribuídas à manipulação de sua carreira pelo mesmo Di Veras, muito presente no momento mais brilhante de seu percurso, nos anos 50 .

12 A este respeito, vale a pena recordar uma marchinha de Miguel Gustavo, lançada com grande sucesso em 1958 na interpretação do palhaço Carequinha. Chamava-se "Fanzoca de rádio" e tinha uma letra que não dissimulava a visão depreciativa e o preconceito de classe acerca das frequentadoras dos programas radiofônicos de auditório: "Ela é fã da Emilinha / Não sai do César de Alencar / Grita o nome do Cauby - Cauby! / E depois de desmaiar / Pega a Revista do Rádio / e começa a se abanar // É uma faixa aqui, outra faixa ali / E o dia inteirinho ela não faz nada / Enquanto isso na minha casa / Ninguém arranja uma empregada [...]” 


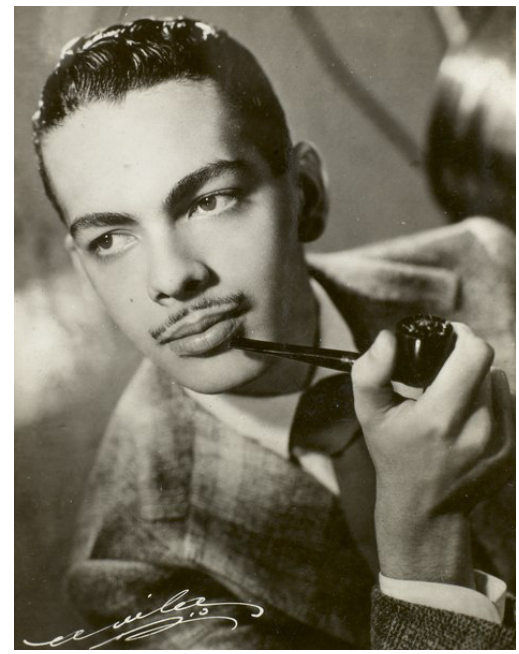

Fig. 4 : Cauby Peixoto em 1956. Foto usada na capa do LP Canção do rouxinol. Domínio Público/Acervo Arquivo Nacional https://commons.wikimedia.org/wiki/File:Cauby_Peixoto_(1956).tif

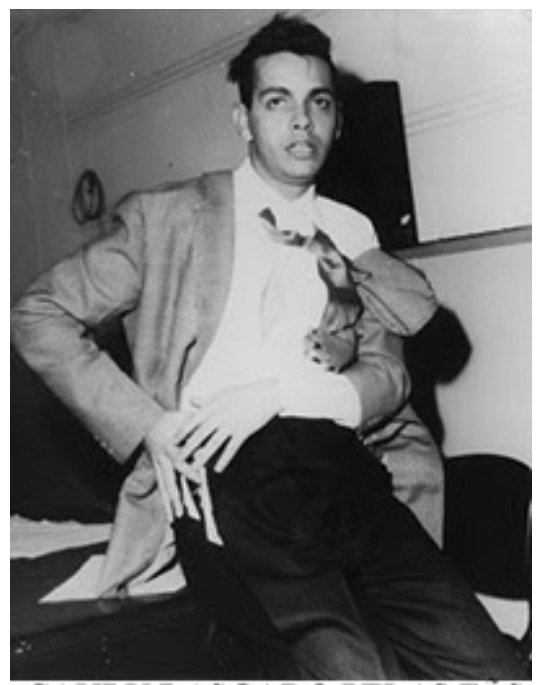

\section{CAUBY RASGADO PELAS FAS}

Fig. 5: Cauby em 1957, com as roupas rasgadas pelas fãs.

Autor: Nancy Lara

https://commons.wikimedia.org/wiki/File:CaubyRasgado.jpg 


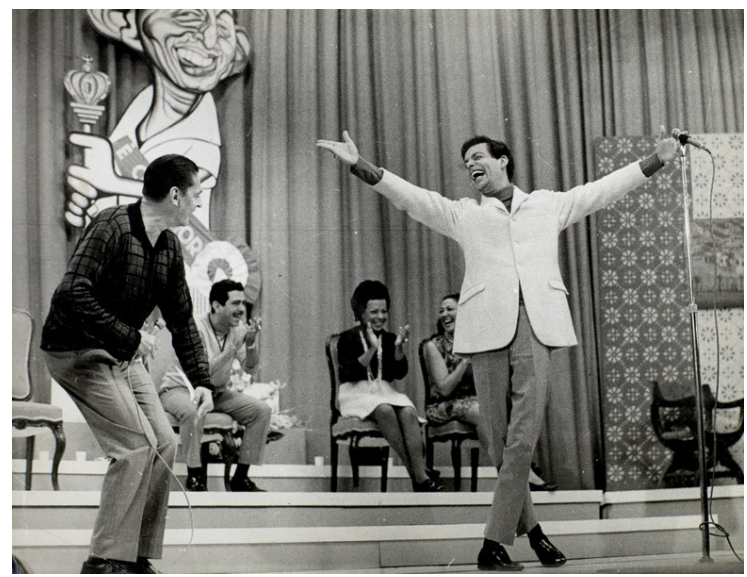

Fig. 6: Cauby no programa de César de Alencar.

DomínioPúblico/AcervoArquivoNacional https://commons.wikimedia.org/wiki/ File:Cauby_Peixoto_em_Dia_com_a_Noite.tif

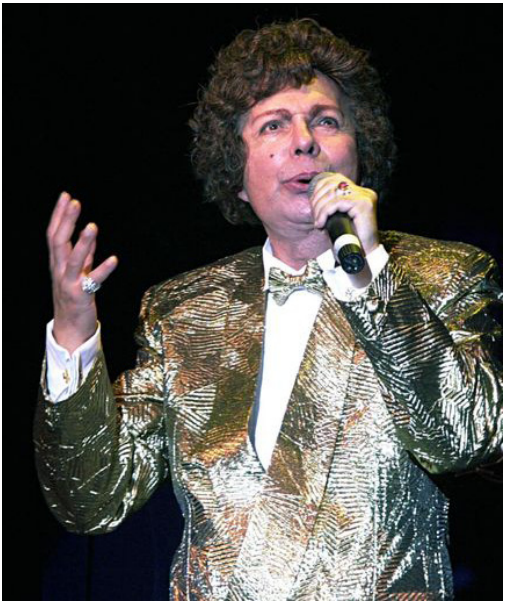

Fig. 7. : Cauby em 2004, cantando no espetáculo de reinauguração da Nova Rádio Nacional. Autor: Ana Nascimento/Agência Brasil https://commons.wikimedia.org/wiki/File:CaubyPeixoto42023.jpeg

Porém, Cauby certamente era muito mais que um produto da inteligência empresarial de Di Veras. Vinha de uma família de músicos, entre os quais se destacou também seu primo Cyro Monteiro. Observe-se que 
os dois seguiram direções praticamente opostas enquanto cantores: enquanto Cyro se distinguiu por uma interpretação baseada na naturalidade da dicção cancional, Cauby cultivou uma estética do artifício.

Profissionalizou-se ainda muito jovem, no final dos anos 40, trabalhando intensamente como crooner, cantor de boate e de rádio. Foi um dos grandes cartazes dos anos 1950, quando reinavam o samba-canção, o bolero e a canção romântica norte-americana. Seu primeiro sucesso foi "Blue gardenia", versão de Antônio Carlos para o fox-canção de Bob Russell e Lester Lee que já fora gravado por Nat King Cole. A nota pitoresca é que a versão deixou no inglês original o primeiro verso da canção, que retomava o título: "blue gardenia", cuidadosamente pronunciado por Cauby como "blu gardinia"; seguiam-se então os versos em português: "Blue gardenia / Flor da recordação / Traz ao meu coração / Lembranças do amor primeiro"...

Ao longo da carreira, gravaria muitas versões e também muitas canções em língua estrangeira, principalmente inglês. Mas o maior sucesso veio, em 1956, com um belo e bem brasileiro samba-canção de Dunga (Valdemar de Abreu) e Jair Amorim: "Conceição", aquela que "vivia no morro a sonhar / com as coisas que o morro não tem".

Em 1960, no LP intitulado O sucesso na voz de Cauby Peixoto, ao lado de faixas selecionadas segundo o modelo dos hits internacionais da hora, o cantor flertava com a bossa nova entoando "A felicidade" de Tom Jobim e Vinicius de Moraes. Porém, neste mesmo ano, e confirmando o perfil musical que mais atraía seu público, seu maior êxito foi um $78 \mathrm{rpm}$ com o fonograma "Ninguém é de Ninguém" (de Toso Gomes, Umberto Silva e Luiz Mergulhão). Esse bolero derramado, com bastante espaço para o cantor se expandir nos agudos, foi o último sucesso da fase áurea de Cauby.

Afirmava-se então a nova era de um canto mais natural, moderno e elegante. As grandes vozes da era do rádio recuaram para segundo plano, e a carreira de Cauby declinou durante muitos anos. Só em 1980, com o lançamento do LP-homenagem Cauby! Cauby!, cujo repertório exibia vários autores de prestígio, seu nome voltou a despertar algum interesse entre as novas gerações.

É importante lembrar que ele sempre foi uma pessoa querida. Os colegas de profissão falam dele com carinho e são unânimes em exaltar seu talento de cantor. Por outro lado, consideram e lamentam que ele tenha submetido sua carreira ao projeto do empresário Di Veras. Zezé Gonzaga, uma das colegas que conheceu o cantor "quando ele começou no 
rádio, antes do 'evento' Di Veras", afirma: “Depois que Di Veras começou a controlá-lo, ele sumiu e ficou irreconhecível. [...] Depois que passou essa fase, voltou a ser a pessoa livre que era antes." (apud FAOUR, 2001, p. 48). Segundo este e outros depoimentos, o empresário teria de certo modo isolado Cauby, levando-o a atitudes extremas em prol da carreira, como arrancar os dentes e colocar uma prótese.

Uma leitura mais ou menos apressada e óbvia apresentaria a relação entre Di Veras e Cauby como ilustração de um processo artificioso de construção da figura camp, confirmando certo mau juízo que às vezes se faz do próprio estilo assim denominado. Porém a questão é certamente mais complicada. Por um lado, Di Veras realmente contribuiu para o sucesso de Cauby, com estratégias e truques publicitários, bem como uma seleção rigorosamente comercial do repertório. Mas hoje é fácil verificar que o principal artífice do estilo de Cauby foi ele próprio, até um ponto aparentemente desaprovado por Di Veras. Este era responsável pela montagem do sistema de marketing em torno do cantor. Mas a longo prazo Cauby seguiu suas inclinações pessoais, num sentido aliás compatível com o atributo camp, cultivando sem peias o exagero e a demanda ansiosa por publicidade. Na ótica do intérprete, o destaque almejado e alcançado por ele, como por qualquer artista, decorreria naturalmente de certa "personalidade" configurada por traços distintivos, diferenciais, os quais transcenderiam inclusive as compartimentações de gênero. É o que ele declara em 2001, no final de uma entrevista à Folha de São Paulo:

Di Veras não gostava dos penteados nem das roupas extravagantes. Eu é que fui colocando. [...]

A vaidade não me deixou sofrer. O nariz é torto? Conserta. Ih, como fiz essas coisas. Ruim é não falarem da gente, é ficar no ostracismo. O artista tem que ter personalidade. Nem penso se fulano é homem ou não é, se é mulher ou não é. Ou me arrepia ou não. Aplaudo ou vou embora. Folha - Segundo o livro, você cometeu vários exageros ao longo de sua carreira. Você concorda?

Cauby - Concordo. Por causa do machismo do Di Veras. Exagerei porque ele queria que eu fosse um cantor sério. Sério eu seria o quê? Uma cópia do Frank Sinatra, de smoking, casado, com filho. (PEIXOTO, 2011)

Então talvez lhe caiba bem a definição singela usada em 2007 por um programa de rádio para apresentá-lo aos ouvintes: "uma das grandes 
personalidades da música popular brasileira, não apenas por ter uma voz espetacular, mas também por ser um espetáculo de artista com um modo de ser extravagante que foi de encontro a todo e qualquer padrão rígido de comportamento." (Estúdio F, 2019)

Em larga medida, esse "modo de ser" era um apanágio da figura pública, do personagem que militava no mundo do show business. Segundo relatos, em casa, ele gostava mesmo era de vestir pijamas. Mas no palco, cobria-se de brilhos - e brilhava! Sua vigorosa e sedutora presença em cena fascinou um olho teatral como o de Sergio Britto, particularmente impressionado com as entradas do intérprete no palco: "O segredo do Cauby é esse. Ele entra, dá uma olhada para toda a plateia, se faz de vedete e, ao mesmo tempo, critica essa mesma vedete." (apud FAOUR, 2001, p. 30),

Mas Sergio completa: "Afora o prazer de ouvi-lo cantar, a entrada dele vale o show todo." (apud FAOUR, 2001, p. 30) De fato, é preciso, como fazem quase todos, destacar este ponto: o principal trunfo de Cauby sempre foi sua voz, sublinhada no título de sua biografia por Rodrigo Faour: Bastidores: Cauby Peixoto: 50 anos da voz e do mito. Admiradíssimo por outros intérpretes e artistas da canção popular, foi várias vezes apontado como o maior cantor do Brasil.

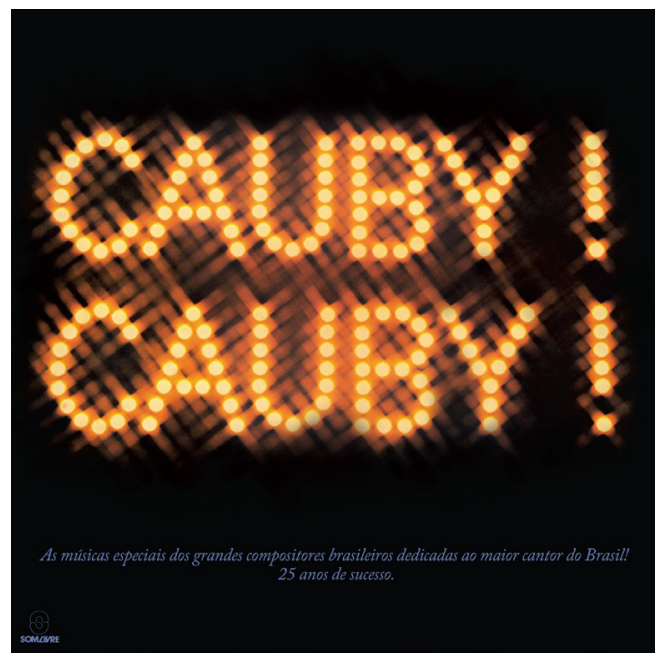

Fig. 8: capa de Cauby! Cauby!, Som Livre, 1980

Foto: Cláudia Neiva de Matos 
Duas das melhores faixas no já mencionado LP Cauby! Cauby!, que o resgatou do semi-esquecimento em 1980, apontavam justamente seu talento de cantor e sua brilhante performance no palco, arrebatando as plateias.

"Cauby! Cauby!", de Caetano Veloso, parte de uma fantasia poética em torno do nome indígena do cantor, evocando sensações da natureza e afetos primevos.

Lembro eu deitado na relva

No frio da manhã

Numa clareira da aldeia Tupi

Entre mil pássaros só uma voz

Uma voz, minha mãe

Música doce

Chamando meu nome

Cauby! Cauby! [...]

Neste cenário edênico soa e ressoa a voz original, a voz materna, que depois se multiplica, duas estrofes adiante, em numerosas vozes que se erguem para chamar e celebrar o cantor, agora presente na cena dos auditórios repletos de fãs em delírio:

\section{[...] Depois mil vozes ouvi}

Que me queriam chamar

Que me queriam levar de mim

Tantas mulheres febris

Loucas pela minha voz

Música doce

Gritando meu nome

Cauby! Cauby!

Cauby! Cauby!

A canção termina com o coro das fãs num crescendo de volume que ultrapassa a música e a canção, ao mesmo passo em que se explicitam o contraste e a analogia entre as energias primitivas e a potência da moderna cultura urbana de massas, com seus prazeres ambíguos e extremados: 
Hoje deitado na selva do nosso lugar

Copacabana lá fora a rugir

Oh! Meu amor proibido

Eu te vejo chegar

Música doida

Carícias no ouvido

Cauby! Cauby!

Cauby! Cauby!

Cauby! Cauby!

"Bastidores", ${ }^{13}$ de Chico Buarque de Holanda, opera também a partir de contrastes, mas num escopo temporal totalmente diverso. Cena pública e cena privada - o camarim, o palco, a casa - se alternam em rápida sequência, num turbilhão de emoções extremadas e contrastantes - conjunção apaixonada entre artista e público, abandono e solidão do indivíduo "real".

O tema de "Bastidores" é a própria existência cindida do cantor, figura pública da glória e figura privada do infortúnio, personagens contrastantes que ele performatiza em diferentes cenários. Chico (em entrevista de 05/04/1999 a Santuza Cambraia Naves14) explicou que "Bastidores" foi feita originalmente para sua irmã, a cantora Cristina Buarque: "eu adoro a gravação dele e adoro o Cauby. Mas na verdade eu não fiz pensando no Cauby cantando no feminino, eu não faria isso com ele. [...] Às vezes o equívoco também dá certo. Mas eu nunca escreveria para o Cauby, não tinha essa intimidade de escrever para ele uma música gay."

Ainda assim, a composição de Chico cai como uma luva na voz e na figura de Cauby, valorizando seu vigor e amplitude de emissão, seu estilo feito de arroubos e fulgurações tendentes ao kitsch, seu culto da fantasia com doses de mistificação - "com muitos brilhos me vesti / depois me pintei me pintei me pintei..." Mesmo a ambigüidade sexual do intérprete parece insinuada e esteticamente explorada: sem que se defina morfologicamente o gênero do sujeito em nenhuma passagem do texto,

13 Retomo aqui algumas observações que fiz numa análise mais completa dessa canção, num texto intitulado "A face oculta do artista: o compositor e o intérprete de canções" (2007).

$14 \mathrm{O}$ texto da entrevista me foi gentilmente cedido para consulta, em 2013, pela Professora Santuza C. Naves, de saudosa memória. 
seu público é assim descrito por ele: "e os homens lá pedindo bis / bêbados e febris / a se rasgar por mim".

Entre o melodrama e o music-hall, o clown exibe suas máscaras e caricaturas patéticas. Arma e desarma o velho jogo da vida humana, esplendor e miséria na cena dividida entre palco e bastidores, público e privado, show e solilóquio. No fundo suas duas faces estão conectadas. Fazendo pensar na figura arquetípica do palhaço que chora em segredo, o drama pessoal do intérprete ao mesmo tempo contrasta e colabora com o brilho do seu desempenho no palco: "Como é cruel cantar assim! [...] Nem sei como eu cantava assim! [...] Jamais cantei tão lindo assim!"

Com tudo isso, Cauby parece mesmo um prato cheio pra se falar de camp. Realmente, ele tem sido objeto de muitos rótulos e categorizações associados ao camp e frequentemente depreciativos: kitsch, brega, cafona e, com inflexão discriminatória, gay. No site /letras.mus.br/, entre montes de "estilos musicais", Cauby está no setor "brega" (site Letras: 2013)

Mesmo seu biógrafo e fã Rodrigo Faour, ao longo do livro, constantemente distingue o que considera serem elementos de qualidade na obra de Cauby e a parte "cafona" no seu repertório.

\section{Camp? o estudo, o manifesto}

Voltamos agora a algumas das considerações que estavam no início deste artigo.

Vimos que o significado de "camp" frequentemente embute boa dose de subjetividade, isto é, remete não somente ao próprio objeto considerado camp, mas também ao sujeito que usa o termo para qualificar tal objeto. Em larga medida, é uma questão de gosto: usada sem cerimônia, a noção pode funcionar como um pré-conceito. Por isso, no título deste artigo, o termo vem seguido por um ponto de interrogação. E também porque o camp é algo que levanta questões e dúvidas, na medida em que mexe com nossas emoções e ideias de maneira inusual.

Muitos objetos, obras ou personagens não são intrinsecamente camp, mas podem vir a sê-lo quando enfocados à luz de um olhar camp. Um objeto camp é aquele que enxergamos como camp, que provoca em nós o efeito que chamamos camp, ainda que, frequentemente, não estejamos seguros de saber explicá-lo. A palavra "camp" tem a malícia e a maleabilidade da gíria. É difícil fazer dela um conceito, porque ela se recusa à objetivação. É, ao mesmo tempo, um modo de olhar e uma atribuição de qualidades um tanto ambivalentes e obscuras; um indício de que algo ou alguém tenta nos 
seduzir e em boa medida, efetivamente, nos seduz, mesmo que também provoque nossa rejeição.

A noção, tal como proposta por Susan Sontag e manejada pela maioria dos comentaristas, é algo construído pela mente do observador sobre um objeto que ele observa e aprecia, com muito interesse e ao mesmo tempo com uma margem de aparente desinteresse, uma ponta de espírito blasé. Este é o ponto de partida dos comentários de Sontag: o camp inspira ao mesmo tempo atração e repúdio.

O olhar intelectual que examina o camp arrisca-se e presta-se a ser afetado por ele. É atraído pelo objeto e ao mesmo tempo dele mantém certa distância, numa operação que envolve ironia e pode também produzir humor. É um olhar que abre a porta da paródia. O objeto camp é aquele que se presta à paródia, que é ele mesmo uma paródia, ou que é visto como paródia.

Pedro A. Leite relaciona a defesa que Sontag faz, nas suas "Notes on camp", de um "sistema de valores estético diferente, não mais baseado em expectativas ortodoxas em relação à obra de arte" (LEITE, 2011, p. 33), e o título do livro onde se encontra o ensaio: Contra a interpretação. Segundo Leite ( o que a autora chama ali de

interpretação - a adoção de uma postura crítica visando desnudar a obra de sua forma, seja lá qual seja, e mostrar as intenções, pulsões e esquematismos por trás dela - parece a abordagem 'séria' em relação aos produtos da indústria cultural que ela afirma ter sido demolida pelo camp. (LEITE, 2011, p. 33)

E acrescenta:

A defesa de uma maior sensibilidade no trato com a arte e suas encarnações mais triviais (indústria cultural) em detrimento da tentativa de entendê-la é bastante rebelde quando localizada dentro do contexto do debate acadêmico, que justamente sempre pretendeu domar a arte através da interpretação. (LEITE, 2011, p. 34)

Por um lado, isso confere sentido inovador e libertário tanto à ótica camp quanto aos objetos que ela aloca nessa categoria. Por outro lado, pode-se entender que aí se perpetra uma espécie de violência contra o objeto classificado como camp. Pois a visão ou categoria camp, destacando a forma e a exterioridade, secundarizando ou desprezando o conteúdo ou sentido - e portanto dispensando a interpretação - de certo modo "esvazia" seu objeto, condena-o a permanecer à margem, a submeter-se a certa redução ou rebaixamento. 
Talvez, naquele início dos anos 60, Sontag não estivesse ainda em condições de perceber claramente esse problema. Quando redigiu suas "notas", estava mergulhada na novidade e estranheza da cena camp, tomada por reações contraditórias de fascínio e repúdio. E estava explorando pioneiramente, com sensibilidade crítica e coragem, um mundo de formas e sensações que escapavam aos hábitos e critérios canônicos e das próprias vanguardas "clássicas".

Quase quarenta anos depois, quando Denilson Lopes elabora o ensaio "Terceiro manifesto Camp", já é possível situar o camp, como objeto de reflexão e avaliação, num panorama bem mais assentado: pela bibliografia específica já disponível; pelas perspectivas transformadoras do pensamento pós-moderno; e pela configuração de uma história consistente da cultura LGBT. O autor pode então abordar seu objeto de modo criterioso e abalizado, mas também delicado e empático. Vale a pena sublinhar e examinar algumas ideias do texto de Denilson, que trazem um ponto de vista mais atual, familiarizado com os caminhos que o camp percorreu nas últimas décadas, na história sociocultural e na elaboração crítica. O que permite projetar o conceito e buscar seu significado num âmbito mais amplo, multifacetado e dinâmico:

Mais do que uma forma de recepção, "categoria de gosto cultural" (ROSS, A.: 1993, 55) ou modo de comportamento (BOOTH, M.: 1983, 179), o camp é uma categoria que estabelece mediações, transita entre objetos culturais e o conjunto do social, é mutável no decorrer do tempo e possui uma história e uma concreção delimitáveis, constituindo um conjunto de imagens e atitudes, que por ora podemos chamar não de uma tendência artística, um estilo, mas de um imaginário que tem um papel singular e relevante. (LOPES, 2002, p. 96)

O destaque dado por Sontag ao sentido estético do camp é retomado por Denilson. É a hipertrofia desse sentido que caracteriza as figuras camp e estabelece nexos de historicidade entre elas: "Uma linhagem de estetas da vida, artistas ou não, foi delineada, dos poetas malditos românticos aos dândis decadentistas e punks góticos." (Lopes, 2002, p. 100)

$\mathrm{Na}$ ótica do autor, contudo, a exacerbação da aparência sensível não oblitera nem desmente a energia interna (o "conteúdo") das formas estéticas. O jogo das aparências, das representações, dos artifícios, expressa a insatisfação e o afã de sujeitos submergidos na sociedade de massas, na crise do individualismo contemporâneo. "A subjetividade, que se pretendia liberta da sociedade, fragmentou-se, de forma crescente, até o processo de perda 
de uma identidade individual claramente definida." (LOPES, 2002, p. 90)

Crise e fragmentação são categorias axiais para narrar a subjetividade contemporânea, aos quais o pensamento pós-moderno dedicou muita atenção. $\mathrm{O}$ texto de Denilson concentra-se em observar esses tópicos no âmbito da cultura gay, tal como ela se manifesta nas linguagens camp. Esta é uma divergência marcante de sua abordagem em relação à de Sontag. Para o autor, a comunidade gay é parte essencial de um grande jogo de ficcionalização ou estetização da vida cotidiana, implicando "uma revitalização lúdica da comunicação, da representacão, artifício de sedução e liberação de uma identidade individual única." (LOPES, 2002, p. 95). O espaço público é ocupado por grupos de indivíduos em transformação, cujo desafio "é articular suas máscaras em constante troca, seu eu mutante, sem se deixar dissolver no puro movimento, na velocidade, no mercado de imagens." (LOPES, 2002, p. 93) Isso configura um novo "paradigma estético", protagonizado sobretudo pela comunidade homosssexual.

Dentro desse novo paradigma é que o camp ganha mais interesse, para o que é necessário redimensionar a problemática da homossexualidade posta à deriva. O camp, nas suas origens, não pode ser chamado de fundamentalmente gay, mas especialmente nesse século tornou-se um elemento definidor, sem ser totalizador, da identidade homossexual. (LOPES, 2002, p. 94)

A reflexão de Denilson é sustentada por volumosa bibliografia teórica, que ele percorre desde o início do texto. Examina, na obra de diversos pensadores, conceitos e propostas capazes de dar perspectiva filosófica, sociológica e semiótica para apreender teoricamente a estética e a ideologia do camp. Conceitos como representação, artifício e simulacro são revistos e reavaliados, geralmente no sentido positivo de uma comunicabilidade agregadora. O travesti, que "é por excelência o ser de um mundo simulacral" (LOPES, 2002, p. 100), é a figura mais exemplar dessa discussão:

$[\ldots]$ o que me interessa mais é perceber o travestimento como valorização do artifício enquanto categoria central, em estética (ver ROSSET, C.: 1989 e SCARPETTA, G.: 1988) e na composição de uma identidade performativa do sujeito contemporâneo. O travestimento nos atravessa, não nos fala apenas de um outro distante [...]" (LOPES, 2002, p. 103)

Para captar e reconhecer esse atravessamento, essa fantasia compartilhada que aproxima os seres, é preciso liberar e cultivar os "afetos e poses", que davam título ao Seminário organizado por Denilson. Isso 
exige um movimento da consciência crítica que ultrapassa os próprios limites, deixando-se arrastar pelo corpo e pela imaginação. É muito bonito perceber como o texto de Denilson perfaz aos poucos esse caminho. Partindo de um discurso compenetrado, lastreado por alentada bibliografia, ele parece, à primeira vista, cumprir a intenção ou tentativa de certa "neutralidade" na avaliação do camp. Mas, no desenrolar do texto, o autor vai desvelando progressivamente uma adesão íntima a seu objeto, associando ética e estética para acolhê-lo com empatia e empenho assumidamente pessoal. Ao mesmo passo, avança na percepção de seu caráter afetivo: uma afetividade que renuncia à pretensão de autenticidade do sentimentalismo romântico para resgatar e celebrar a energia positiva de uma teatralidade exuberante, a alegria do encontro e da comunicação movendo os artistas e seu público. A elaboração intelectual resulta em posição assumida em favor do objeto, em convite à participação afirmativa, conforme já anunciava o título do ensaio: "Terceiro manifesto camp".

O elemento gay ganha destaque, mas também é ultrapassado pela integração de todas as diferenças. Na visão do autor, a subjetividade pós-moderna, fragmentada e incapaz de se definir pela identidade individual, abre-se e expande-se para acolher o outro, integrar-se nos gestos e condutas ritualizados, na performance coletiva. A alegria que o camp oferece generosamente, no seu abraço escancarado, afasta, mesmo que provisoriamente, a sombra da solidão. Para os sujeitos reunidos nessa cena, a efemeridade das poses toma vulto e validade, pela conexão dos afetos destravados. E podemos compreender melhor a epígrafe do texto de Denilson, a qual, de saída, pelas palavras de Friedrich Nietzsche, cancela a ideia de um camp superficial, vazio de conteúdo: "Tudo que é profundo gosta de máscara."

É preciso lembrar que o fator afetivo, que aproxima os seres, celebra a comum humanidade e legitima a alegria da festa, já estava, com menor relevo, no ensaio de Sontag: "Camp taste is a kind of love, love for human nature. [...] Camp is a tender feeling." (SONTAG, 2013, p. 10) ${ }^{15}$ Mas Denilson investe nele com mais convicção, coloca-o no eixo de sua leitura, ao mesmo tempo que, enquanto sujeito crítico, ocupa nela um lugar de responsabilidade assumida com amor. Isso afeta radicalmente a relação do estudioso com seu objeto e a imagem de ambos que do estudo

15 "O gosto Camp é um tipo de amor, amor pela natureza humana. [...] O Camp é um sentimento terno." 
resulta, podendo apontar para uma proposta abrangente de renovação do próprio discurso crítico e da experiência de recepção crítica:

O camp traz algo recalcado na arte e crítica modernas: a afetividade, mesmo a identificação com a obra e com seu autor.

O que há de estranho nos trejeitos, no gosto pela disco, pelas canções francesas ou por melodramas é menos o ridículo do exagero e mais nosso fascínio pelo sentimentalismo que insistimos em revelar de outra forma, encobrindo-o pela ironia e pelo cinismo, considerando-o um escapismo idealizante. (LOPES, 2002, p. 112)

A "nova educação sentimental" (LOPES, 2002, p. 113) praticada pelo camp não busca sinceridade nem constância, mas pode resgatar almas aprisionadas pelo isolamento, pela exclusão, pelo ressentimento. Uma teatralidade redentora nos oferece o palco compartilhado, onde ainda possamos falar em alegria e felicidade. E onde nos alcança o convite imperativo que o autor dirige a seus leitores, ao final do texto: "Faça uma pose. Eu faço. Agora.” (LOPES, 2002, p. 113

\section{Cauby!}

Havendo assim tratado de elaborar a noção de camp, eu deveria estar aparelhada para retornar a Cauby e encontrar seu lugar no discurso acadêmico. E no entanto... parece-me que explicar meu encanto por Cauby mediante o recurso ao conceito do camp continua sendo insuficiente ou insatisfatório. Minha escuta e apreciação de Cauby continuam não cabendo dentro da noção - o que equivale a declarar que o próprio Cauby, pelo menos para mim, não é simplesmente, ou completamente, ou realmente um artista camp (ainda que seja um excelente exemplo a oferecer quando falamos disso).

Talvez isso se deva justamente à experiência da identificação com a obra e seu autor, cujo recalque na crítica moderna foi apontado por Denilson Lopes. Para o olhar que aceita o camp, tal identificação pode ser resgatada. Mas também pode ser que esse resgate, uma vez consumado, dispense o próprio conceito com o qual se justificou.

Como a palavra silenciosa no papel pode dar conta de uma arte capaz de provocar as sensações que Cauby me provocou? Sim, elas tinham um jeito camp. De certo modo, poderiam lembrar a arte do travesti tal como apresentado por Denilson: "cindido entre o exagero da afetividade e a festa das aparências” (LOPES, 2002, p. 100). Havia, sim, em Cauby, 
um exagero da afetividade e uma festa das aparências; mas, pelo menos para meus olhos e ouvidos, não havia nenhuma cisão.

Para (não) explicar isso melhor, volto ao início dos anos 1980, quando assisti, no Teatro João Caetano, numa daquelas séries de espetáculos a preços populares, a um show de Cauby Peixoto. Acho que foi por causa desse show que escolhi Cauby como tema deste artigo. Pois saí dali com uma fortíssima impressão que me fez considerar e declarar, como por muitos anos e talvez ainda hoje pude continuar declarando, que foi o melhor show que vi na minha vida.

Uma das coisas que me arrebatou, além evidentemente da fantástica performance vocal do cantor, foi sua empatia com a plateia. Esta não era propriamente composta de "macacas de auditório", e sim de velhinhas deliciadas, assim como eu mesma (que naquele tempo ainda não era uma velhinha) me deixei deliciar por aquela arte para mim ainda bastante desconhecida e um tanto exótica.

A memória pode me trair nos detalhes, mas dois momentos ficaram bem marcados e permanecem nítidos.

Readentrando no palco com o segundo figurino da noite, Cauby canta "Bastidores", o sucesso do seu disco recém-lançado. Quando chega à parte da letra que diz "com muitos brilhos me vesti", ele abre de repente o paletó e entrega aos olhos da plateia o torso coberto por um colete de cintilantes paetês. O brilho que o veste, generosamente ostentado para gozo dos olhares presentes, vem de dentro, do peito escancarado. O que a letra nos faz compreender é que se, por um lado, o "sentimento" real do indivíduo dilacerado pelo abandono e pelo amor fracassado parece obliterado pelo artifício da vestimenta e da maquiagem, pelas luzes do palco, por outro, esse sentimento, seja ele qual for, na verdade funciona como motor emocional para fazer o personagem atingir sua plenitude: "Como é cruel cantar assim!" diz a canção. Mas também: "Jamais cantei tão lindo assim!"

Esse encontro de intensidades arrebata o público que escuta e olha. E na catarse harmonizada pela voz precisa do cantor, você se rasga também, e você reluz!

No final do show, retirando-se do palco após muitos bis e já distante do microfone, Cauby sai de cena andando de costas, recuando para os bastidores, deixando-se a contragosto subtrair aos olhos do público; e ainda falando para sua plateia, já sem poder se fazer ouvir mas compreendido por todas e todos através dos movimentos de sua boca que nitidamente exclamam: "Eu amo vocês! Eu amo vocês!" 
Nós acreditamos. E nós também amamos Cauby.

Como é possível imaginar que tal arte careça de "conteúdo"? Ali existe, sim, com certeza, um sentido: intenso, interior, um tanto oculto, até silenciado, mas capaz de fulgurar no momento preciso. Como se, no fundo, o conteúdo permanecesse subjacente à cena, tornando-a mais insinuante e saborosa. $\mathrm{O}$ artifício é sincero, está dentro, vem de dentro. $\mathrm{O}$ artifício é arte.

Nas duas canções que mencionei, de Chico e Caetano, a letra sublinha a existência desse conteúdo oculto, íntimo, portador de enorme carga emocional. É pose, mas também é afeto, conforme rezava o título do Seminário da UERJ. Essas duas forças não se excluem necessariamente, conforme indica Denilson Lopes: "o camp se situa num espaço de deriva entre categorias, vistas em outros contextos como antitéticas - como, de um lado, teatralidade, ironia e percepção do absurdo dos sentimentos extremos, e, de outro, autenticidade, intensidade e afirmação dos sentimentos extremos." (LOPES, 2002, p. 98)

Mas é preciso ir ainda mais fundo, é preciso ir além da ironia. Pois as velhinhas do Teatro João Caetano, como as fãs dos auditórios do passado, adoravam Cauby sem ironia e sem conflito. A ironia se impõe em boa parte a partir de uma ótica ilustrada, ou que se pretende ilustrada, de elite. Se Cauby pode ser camp para nós acadêmicos mas não pode ser camp para os seus verdadeiros fãs, como nós classificaríamos ou entenderíamos, então, o Cauby dos verdadeiros fãs?

Então, declaro-me aqui a favor do camp - e a favor da interpretação também! Declaro-me uma verdadeira fã de Cauby, reconhecendo como verdadeiro o sentimento que tive naquele show no João Caetano no início dos anos 80 . Isso posto, uma vez que há em mim, com certeza, um olharou um ouvido - que indisfarçavelmente aprecia, e até adora, Cauby, será que careço da angulação camp para viabilizar sua presença entre os meus artistas mais queridos na canção popular brasileira?

Essas questões me mantêm indecisa em relação à ideia de camp.

Por um lado, ela parece ser uma ferramenta conceitual útil para uma parte do pensamento acadêmico, pois é capaz de levantar, instabilizar, problematizar diversas questões relativas ao gosto, à formação do cânone e suas margens. Por outro lado, parece um instrumento ultrapassado. No nosso tempo, e ao cabo de um processo que já vem de longe, o cânone está corroído por todos os lados, e as hierarquias do gosto bastante desmoralizadas. 
Conclusão: não sei bem o que fazer com essa categoria do camp hoje em dia, quando a sensibilidade e o gosto, e particularmente o meu gosto, parecem tão liberados de normas e circunscrições. A era pós-cânone e pós-moderna provavelmente também é uma era pós-camp. Talvez o conceito só sobreviva como casca oca, esvaziada do sentido que um dia habitou ali.

Já o encanto, este continua presente. E Cauby, embora morto, ainda ecoa em nossas vidas. Mesmo que você não tenha tido a chance de ouvi-lo ao vivo. Ponha Cauby!Cauby! no player e aumente o volume. Algo há de acontecer, mesmo que você não saiba fazer uma pose.

Então é isso! Quando a voz dele me arrebata e faz as ideias dançarem, não me pergunto:

É camp?

Porque já sei muito bem:

É Cauby!

\section{REFERÊNCIAS BIBLIOGRÁFICAS:}

Camp: Notes on Fashion. Site Itsliquid. 16/01/2019. Disponível em $<\underline{\text { https:// }}$ www.itsliquid.com/camp-notes-on-fashion.html>. Acesso em 15 nov. 2019.

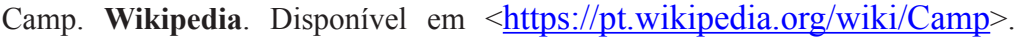
Acesso em 05 ag. 2019.

DAPIÈVE, Arthur. Alô, alô, exagero: Lady Gaga traz de volta o estilo Camp. Lola. 23/10/2012. Disponível em $<$ https://mdemulher.abril.com.br/famosos-e-tv/alo-alo-exagero-lady-gaga-traz-de-volta-o-estilo-camp/>. Acesso em 03 dez. 2019.

DINIZ, Pedro. Conheça o camp, a onda que contagiou de Elton John a Lady Gaga (Parece esquisitice, e é mesmo. Entenda como o termo da moda vai mudar a forma de você consumir). Exame. 23/05/2019. Disponível em $<$ https://exame.abril. com.br/revista-exame/o-que-e-camp/ >. Acesso em 10 out. 2019.

Estilo Camp. Site HiSoUR. Disponível em <https://www.hisour.com/pt/ camp-style-35939/>. Acesso em 20 out. 2019.

Estúdio F- $\mathrm{n}^{\circ}$ 84. Roteiro para programa radiofônico. Apresentação de Paulo César Soares. Momentos Musicais da Funarte. Rádio Nacional. Disponível em $\leq$ http://www.funarte.gov.br/wp-content/uploads/2009/12/EF84.Cauby-Peixoto. pdf $>$. Acesso em 01 nov. 2019. 
FAOUR, Rodrigo. Bastidores: Cauby Peixoto - 50 anos da voz e do mito. Rio de Janeiro: Record, 2001.

LEITE , Pedro de Araújo. Adorno e Horkheimer versus Batman e Robin: da estética camp como possibilidade de superação de alguma coisa. Mestrado em Teoria Literária. São Paulo: Unicamp, 2011. Disponível em $<\underline{\text { http://www.biblio- }}$ tecadigital.unicamp.br/document $/$ code $=000794959 \& \mathrm{fd}=\mathrm{y}>$. Acesso em 01 fev. 2014. Letras. <https://www.letras.mus.br/mais-acessadas/brega/>. Acesso em 22 mai. 2013.

LOPES, Denilson. Terceiro manifesto camp. In O homem que amava rapazes. P. 89-120. Rio de Janeiro: Aeroplano, 2002.

MATOS, Cláudia Neiva de. "A face oculta do artista: o compositor e o intérprete de canções”. In VALENTE, Heloísa de Araújo Duarte (org.). Música e Mídia: novas abordagens sobre a canção. P.175-189. São Paulo: Via Lettera/Fapesp, 2007.

PEIXOTO, Cauby. Entrevista a SANCHES, Pedro Alexandre. Cauby Peixoto lança biografia que fala de armações e sexualidade. Folha de São Paulo, 24/11/2001. Disponível em < http://www1.folha.uol.com.br/folha/ilustrada/ ult90u19291.shtml >. Acesso em 10 out. 2019.

PEIXOTO, Cauby. LP Cauby! Cauby! Som Livre, 1980.

RODRIGUES,Thiago. Extravaganza : definição, histórico e exposição da estética camp. Disponível em <http://bdm.bce.unb.br/handle/10483/3220>. Acesso em 15 nov. 2019.

SONTAG, Susan. Notes on camp. In . Against Interpretation. 1966. Disponível em http://classes.dma.ucla.edu/Spring15/104/Susan\%20Sontag \%20Notes\%200n\%20-Camp-.pdf. Acesso em 20 abr. 2013.

\section{REFERÊNCIAS ICONOGRÁFICAS:}

Fig. 1: Cher, 2019. Autor: Raph_PH

https://commons.wikimedia.org/wiki/File:CherO2201019-6 (48933060976) cropped.jpg

Acesso em 10/04/2020.

Fig. 2: Carmen Miranda, 1939. https://commons.wikimedia.org/wiki/ File:Carmen Miranda, November 1939.jpgig

Acesso em 10/04/2020. 
Fig. 3: Maria Bethânia, 2015. Autor: Sebástian Freire. https://commons.wikimedia.org/wiki/File:Maria_Beth\%C3\%A2nia no Vivo Rio_- Turn\%C3\%AA_Abra\%C3\%A7ar_e_agradecer_DSC00728 (20744971684).jpg

Acesso em 10/04/2020.

Fig. 4: Cauby Peixoto em 1956. Foto usada na capa do LP Canção do rouxinol. Domínio Público / Acervo Arquivo Nacional. https://commons.wikimedia. org/wiki/File:Cauby_Peixoto_(1956).tif

Acesso em 10/04/2020.

Fig. 5: Cauby em 1957, com as roupas rasgadas pelas fãs. Autora: Nancy Lara.

https://commons.wikimedia.org/wiki/File:CaubyRasgado.jpg Acesso em 10/04/2020.

Fig. 6: Cauby no programa de César de Alencar. Domínio Público / Acervo Arquivo Nacional. https://commons.wikimedia.org/wiki/File:Cauby_Peixoto_em_Dia_com_a_Noite.tif

Acesso em 10/04/2020.

Fig. 7: Cauby em 2004, cantando no espetáculo de reinauguração da Nova Rádio Nacional. Autor: Ana Nascimento / Agência Brasil. https://commons.wikimedia.org/wiki/File:CaubyPeixoto42023.jpeg

Acesso em 10/04/2020.

Fig. 8: capa de Cauby! Cauby!, Som Livre, 1980. Foto de: Cláudia Neiva de Matos

Recebido em: 31/07/2019

Aceito em: 30/11/2019 